\title{
THE IMPROVEMENT OF STUDENT COMPETENCY IN A CLINICAL STUDY IN INDONESIA: WHAT FACTORS PLAYED AN IMPORTANT ROLE?
}

\author{
Muhammad Hadi*, Achir Yani S. Hamid**, Sudijanto Kamso***, Sutoto Sutoto****, \\ Ahmad Watik Pratiknya $* * * * *$, Nursalam Nursalam******, Ferry Efendi******* \\ * Faculty of Nursing, Universitas Muhammadiyah Jakarta, Indonesia \\ ** Indonesian National Nurses Association, Indonesia \\ *** Faculty of Public Health, Universitas Indonesia, Indonesia \\ **** Komite Akreditasi Rumah Sakit, Indonesia \\ ******Faculty of Medicine and Health Sciences, Universitas Muhammadiyah Jakarta, Indonesia \\ ******* Faculty of Nursing, Universitas Airlangga, Indonesia \\ Email: hadi_bintang001@yahoo.co.id
}

\begin{abstract}
Background: The improvement of nursing student competency currently is still an issue for the majority of nursing education institutions in Indonesia. This is due to their partnership with hospitals having not been supported by adequate policies and other factors. Objectives: The purpose of this study is to identify the appropriate model for improving student competency in a clinical study. The design used in this study was an observational study with cross-sectional approach. Methods: The research design used a cross-sectional approach involving five hospitals and five Universities. Three hundred and eighty-four participants were recruited from these sites. The data was analysed using multiple logistic regression. Results: The results showed that the partnership contributed 3.36 times, the patient variations 2.96 times, the job description of the clinical educator 2.30 times, a role model 2.28 times, and the expertise of the faculty educator 2.08 times towards the achievement of student competency in the clinical study. Conclusions: It can be concluded that the partnership aspect, patient variation, job description of the clinical educator, role model, the expertise of the faculty educator, and the level of education has a significant role to improve the achievements coming from the level of student competency in the clinical study. The results of this study can be used by nursing educational institutions, hospitals and the government to organise a nursing education model for the more optimal achievement of the student's competencies.
\end{abstract}

Keywords: partnership, nursing education, competence, hospitals

\section{INTRODUCTION}

The Indonesian Hospital Association in 2012 recorded a number of hospitals throughout Indonesia, as many as 1979 , with the average annual growth being around $1.14 \%$ (Azhary, 2009). The constraints faced by the hospitals includes the lack of competent health resources. This includes the number of nurses, high investment costs, geopolitical issues and public perception. This is still low in relation to the quality of the health services in Indonesia (Azhary, 2009). The growth of the number of hospitals was also followed by a rapid growth in the nursing education institutions (Kurniati and Efendi, 2012). The final report in 2011 from The Health Education Project-Directorate General of Higher Education mentioned that the number of nursing education institutions at a Master's degree level had increased to 12 institutions, and the number of professional education institutions had increased to 112 institutions. The existence of nursing education has not been matched by an adequate arrangement of practices in hospitals, clinics, public health centres, homes for the elderly and the community (AIPNI, 2010). Besides that, the existence of nursing education has not been matched by an increase in the quality and quantity of the lecturer (AIPNI, 2010).

The large number of nursing institution education practices compared with the practice availability currently is still a complicated issue (Myrick and Yonge, 2002). The problem is that the management of clinical education is still poor and the coordination of the achievement of the learning objectives for the students is not going well (Nursalam and Efendi, 2008). The weak management of nursing education is drawn from the results of a survey conducted by The Association of Indonesian Nurses' Educational Institutions and the Indonesian National Nurses Association in 2010 among 33 provinces, which showed that $90 \%$ of nursing education had not met the standards of nursing education provision (Health Professional Education Quality-Project, 2011). Education institutions require hospitals to 
increase their knowledge and to enhance the skills of students (Canadian Nurses Association, 2014). The hospital requires educational institutions to develop science to improve the quality of care (Davis and Irvine, 2003). One of the problems found in Indonesia is that the hospitals are not capable of facilitating clinical practice to increase the student's competence optimally. This is characterised by weak policy support, a low awareness of the values of partnership and joint ownership, the limited human resources of both parties, and the lack of an ideal nursing practice model and the development of the nursing profession (AIPNI, 2010). The students are often confused when practicing in a hospital because of the unfamiliar situations encountered in hospitals (Myrick and Yonge, 2005; Flanagan, Baldwin and Clarke, 2000). This condition causes the nursing students to find it difficult to develop their professional abilities because the clinical study environment has not been well-established previously (Al-Hussami et al., 2011). Therefore, this situation encourages the researchers to design a clinical learning model that emphasises partnerships between hospitals and educational institutions to obtain an optimum competence level to do with clinical study. This research study combines the Practice-Research Model of Curtin University of Technology (2001) and the Collaborative Clinical Education Epworth Daekin Model (2003) with the theoretical approach of King's Goal Attainment (Alligood \& Tomey, 2002). The purpose of this study was to identify the appropriate model for improving student competency in a clinical study.

\section{MATERIALS AND METHODS}

The research was conducted in JanuarySeptember 2013 by a cross-sectional design approach involving five hospitals (Fatmawati Hospital Jakarta, Hasan Sadikin Hospital Bandung, Kariadi Hospital Semarang, Sardjito Hospital Yogyakarta, and Soetomo Hospital Surabaya) and five universities (Universitas Muhammadiyah Jakarta, Universitas Padjadjaran Bandung, Universitas Gadjah Mada Yogyakarta, Universitas Diponegoro Semarang, and Universitas Airlangga Surabaya). The research consisted of variables and demographics such as sex, age and education; support; faculty staff; mastery of the curriculum, the suitability of expertise and provide study guidelines; the fundamental values of collaboration; collegial partnership and collegial ownership; the availability of clinical learning resources; variations inpatient case, clinical facilities, libraries and standards of practice; nurse clinics; support facilities, nursing management, working conditions, career opportunities, job descriptions and role models with the last variable being the achievement of student learning competencies. The research instrument was validated through testing of validity (content and construct) and reliability (Hastono, 2001; Pratiknya, 2011). This research was done to prove that the variables that have been identified are instrumental in shaping a model for improving student competency in a clinical study in a hospital. The process modelling was done using multiple logistic regression as a method for obtaining the statistical relationship between several independent variables and the dependent variable with special features in the form of dichotomous dependent variables (Hastono, 2001; Tabachnick and Fidell, 2001; Supranto, 2004). Prior to this analysis, the researcher selected the candidate variables by conducting a bivariate test.

All of the respondents signed the consent agreement which was conducted voluntarily. This research was approved by the Ethics Committe of Faculty of Nursing Universitas Indonesia and The Health Research Ethics Committee of the Medical Faculty at Diponegoro University. This study also obtained the permission of five hospitals and five universities where the research was conducted.

\section{RESULTS}

The demographic aspects showed that there was a high percentage of women $(76.8 \%)$ with $24.5 \%$ age range between 35-40.9 years old. Respondents' higher education made up $64.8 \%$ of Nurse graduated with $71.1 \%$ of the learner's competence are high (Table 1). Univariate analysis of all of the variables showed that the policy support to the use of a hospital as a clinical study was high at $69 \%$, 
The Improvement of Student Competency in a Clinical... (Muhammad Hadi, et.al.)

Table 1. Details of the variables and respondents $(n=384)$

\begin{tabular}{|c|c|c|}
\hline Variables & $\mathrm{n}$ & $\%$ \\
\hline \multicolumn{3}{|l|}{ Gender } \\
\hline Male & 89 & 23.2 \\
\hline Female & 295 & 76.8 \\
\hline \multicolumn{3}{|l|}{ Age } \\
\hline$<35)$ yrs & 92 & 24 \\
\hline $35-40.9$ yrs & 94 & 24.5 \\
\hline $41-44,9$ yrs & 72 & 18.8 \\
\hline$\geq 45 \mathrm{yrs}$ & 126 & 3.8 \\
\hline \multicolumn{3}{|l|}{ Education } \\
\hline Ners & 249 & 64.8 \\
\hline Graduate/Specialist & 132 & 34.4 \\
\hline Doctor & 3 & 0.8 \\
\hline \multicolumn{3}{|c|}{ Learners competence } \\
\hline Low & 111 & 28.9 \\
\hline High & 272 & 71.1 \\
\hline \multicolumn{3}{|l|}{ Policy support } \\
\hline Low & 119 & 31 \\
\hline High & 265 & 69 \\
\hline \multicolumn{3}{|l|}{ Faculty members } \\
\hline \multicolumn{3}{|c|}{ Mastery of curriculum } \\
\hline Low & 175 & 45.6 \\
\hline High & 209 & 54.4 \\
\hline \multicolumn{3}{|l|}{ Study guides } \\
\hline Low & 166 & 43.2 \\
\hline High & 218 & 56.8 \\
\hline \multicolumn{3}{|l|}{ Expertise } \\
\hline Low & 172 & 44.8 \\
\hline High & 212 & 55.2 \\
\hline \multicolumn{3}{|l|}{ Values } \\
\hline \multicolumn{3}{|l|}{ Peer partnership } \\
\hline Low & 112 & 29.2 \\
\hline High & 272 & 70.8 \\
\hline \multicolumn{3}{|l|}{ Peer ownership } \\
\hline Low & 186 & 48.4 \\
\hline High & 198 & 51.6 \\
\hline \multicolumn{3}{|l|}{ Hospital facility } \\
\hline \multicolumn{3}{|l|}{ Cases variation } \\
\hline Low & 164 & 42.7 \\
\hline High & 220 & 57.3 \\
\hline \multicolumn{3}{|l|}{ Clinic facility } \\
\hline Low & 92 & 24 \\
\hline High & 292 & 76 \\
\hline \multicolumn{3}{|l|}{ Library } \\
\hline Low & 139 & 36.2 \\
\hline
\end{tabular}


High

Standard practice

Low

High

\section{Clinical Nurse}

Facility support

Low

High

Nursing management

Low

High

Working condition

Low

High

Career Opportunity

Low

High

Clarity of job descriptions

Low

High

Role model

Low

High
46

338

12

88

205

53.4

179

46.6

101

283

26.3

73.7

214

55.7

170

44.3

173

45.1

211

54.9

115

29.9

269

70.1

197

187
51.3

48.7

Table 2 - The results of the variable selection of candidates

\begin{tabular}{lc}
\hline Variables & p-value \\
\hline Sex (CC) & 1.000 \\
Age (LR) & 0.319 \\
Education (LR) & 0,001 \\
Clinical Facilities (CC) & 0.037 \\
Nursing Management (CC) & 0.017 \\
Standard of Competency (CC) & 0.677 \\
Role Model (CC) & 0.009 \\
Job Description (CC) & 0.001 \\
Career (CC) & 0.001 \\
Working Conditions (CC) & 0.050 \\
Policy Support (CC) & 0.084 \\
Curriculum (CC) & 0.001 \\
Compliance of Expertise Staff (CC) & 0.001 \\
Learning Guide (CC) & 0.001 \\
Peer Partnership (CC) & 0.001 \\
Peer Ownership (CC) & 0.004 \\
Variation of Case (CC) & 0.001 \\
Hospital's Library (CC) & 0.004 \\
Support Facilities (CC) & 0.021 \\
\hline Ne: CC:Continy Correction LR
\end{tabular}

Note: $\mathrm{CC}=$ Continuity Correction, $\mathrm{LR}=$ Likelihood Ratio 
The Improvement of Student Competency in a Clinical... (Muhammad Hadi, et.al.)

Table 3 - Multiple logistic regression analysis of the achievement of student competence

\begin{tabular}{lccccc}
\hline \multicolumn{1}{c}{ Variable } & B & S.E. & Wald & Df & Exp (B) \\
\hline Suitability and expertise of Faculty Staff & 0.733 & 0.282 & 6.744 & 1 & $2.08^{* *}$ \\
Peer Partnership & 1.215 & 0.272 & 19.993 & 1 & $3.36^{* * *}$ \\
Variation of Case & 1.086 & 0.266 & 16.670 & 1 & $2.96^{* * *}$ \\
Job Description & 0.802 & 0.282 & 8.092 & 1 & $2.23^{* *}$ \\
Role Model & 0.824 & 0.280 & 8.662 & 1 & $2.28^{* *}$ \\
Education & & & 4.991 & 2 & \\
Education(1) & -0.594 & 0.280 & 4.495 & 1 & $0.55^{* *}$ \\
Education(2) & -1.113 & 1.296 & 0.737 & 1 & 0.32 \\
Constant & -1.431 & 0.359 & 15.911 & 1 & $0.23^{* * *}$ \\
\hline
\end{tabular}

$* \mathrm{p}<0.05, * * \mathrm{p}<0.01, * * * \mathrm{p}<0.001$.

while mastery of the curriculum to achieve the specified competencies was $54.4 \%$ high. Study guides provided by the faculty were only at $56.8 \%$ high, expertise and skills made up 55.2\%, peer partnerships $70.8 \%$ high, peer ownership $51.6 \%$ high, and variations in the cases at $57.3 \%$ were categorised as high. Clinic facilities were at a $76 \%$ high, libraries were at a $63.8 \%$ high, $88 \%$ were working at more than the level of standard practice, the support facilities made up $53.4 \%$ of high, the implementation of nursing management $73.7 \%$ high, working conditions $55.7 \%$ low, career opportunities $54.9 \%$ high, $70.1 \%$ was made up by clarity of the job descriptions being high, and role models were at a $51.3 \%$ low.

The selection of the candidate variables used for multiple logistic regression with the chi-square test has been shown in Table 2. Most of the identified variables have been entered as candidate variables except for gender and age. Competency standards has not been included in the multiple logistic regression because it have a value of $p \leq 0.250$.

The final results showed that the variables that contributed to the achievement of the student competencies in the clinical study was partnerships, the expertise of the faculty staff, patient variation, the job description, role models and education (Table 3 ).

The elements of the collaborative models that have a strong role in relation to the achievement of student competence were role models, job description clarity, suitability, the expertise of the faculty staff, peer partnership values, the availability of a variety of cases and education. The most dominant factor is the peer partnership variable. The suitability and expertise of the faculty staff were 2.08 times more likely to relate to the achievement of competence. The value of peer partnership has 3.36 times to relate to the attainment of competence. The availability of the variation in cases in the clinic 2.96 times relates to the achievement of competence. The job description of the clinical nurse relates by 2.23 times and is significantly associated with the achievement of competence. Role models in the clinic are 2.28 times related and significantly associated with the achievement of competence in the learners. Meanwhile the education up to Master's degree, specialist and doctoral level negatively related to the achievement of student competence. The analytical statistics found out that there were no interaction between the role models and job description. The statistical test also found out that the variable of education was not a confounding variable.

\section{DISCUSSIONS}

Partnership between the hospitals and educational institutions is a necessity as a way to increase student competence. Educational institutions play a role in improving the quality of students from the aspect of knowledge, skills and attitudes (Canadian Nurses Association, 2014; Billings and Halstead, 2012). The hospital serves the student as a way to apply knowledge, 
training skills and to give them information about the development of knowledge in the hospital context (Grove, Burns and Gray, 2013; Mantzorou, 2004). The policy on educational partnerships with hospitals is effectively used to address health disparities issues, thus requiring all health services in an appropriate partnership to address wider health problems (World Health Organization, 2001, 2010; Canadian Nurses Association, 2014).

The variety of cases in the hospital played an important role in the achievement of student competence. Students, in handling varied cases in nursing, are encouraged to be able to formulate nursing diagnoses with various cases (Chickerella and Lutz, 2010). The more varied cases encountered by the students is a way of increasing their ability to formulate the problem, and the actions that will subsequently be applied. For a clinical educator, the variations in the patient cases will guide the students to think about different aspects. The students not only focus on the completion of the main problem, but think about some of the problem's details simultaneously (Myrick and Yonge, 2002).

The clarity of the job description as a form of clinical educator provides convenience for the nurses that work in the hospitals to play two roles. The first role is to provide quality nursing care. The second role is to provide guidance to students who utilise the hospital where they work to train their clinical skills (Cherry and Jacob, 2014) The arrangement of the job description is important in order for the clinical educator to play both roles. The arrangements of the job description also provide comfort for the clinical educators and are a form of respect for them because it's how they show they are a good nurse (Burns et al., 2006). In this research, the results show that the duty of clinical educator is an important factor that contributes to the achievement of the student's competence (Chickerella and Lutz, 2010).

The role model in this research plays an important role in the achievement of student competence (Bott, Mohide and Lawlor, 2011). Currently, there is a lack of role models in nursing care (AIPNI, 2010). Clinical nurses who are able to act as a role model have not been found much (Health Professional Education Quality-Project, 2011). However, these factors are important to achieving student competence. The literature has shown that the clinical educator is a role model, mentor, and a mirror for the students. How to speak, act and behave, listen, work, and to make a decision in a specific situation in the nursing service would be an example for the students (Adelman-Mullally et al., 2013; Canadian Nurses Association, 2014; Kim and Shin, 2017). The need of role model was compulsory in order to enhance the best outcome of student competency.

The expertise of the clinical educators and faculty is one of the factors that plays an important role in the achievement of student competencies (Myrick and Yonge, 2002). Clinical educators and the faculty staff are registered nurses who have special training or sufficient education to serve as a role model, resource and mentor for nursing students (Yonge et al., 2012). They prepare the students to achieve a particular competence accordance to the hospital's goals. Nurse educators have a unique and important role in the educational process of the nursing profession (Myrick and Yonge, 2005). These findings further support the idea of the critical role of capable clinical educators and faculty members.

\section{CONCLUSIONS}

The results of this study have concluded that the model for the improvement of student competency includes partnerships, expertise, and suitability faculty staff, the availability of variation in the cases in the clinic, the job description of the clinical nurse, role models and the education of the clinical and faculty educators. These findings suggest that student competencies in the clinical phase should take into account the complex healthcare environment. Improvement can be made by targeting the identified factors that may contribute to the better achievement of student competency.

\section{REFERENCES}

Adelman-Mullally, T. et al. (2013) 'The clinical nurse educator as leader', Nurse education in practice. Elsevier, 13(1), pp. 29-34.

AIPNI (2010) Kurikulum Pendidikan Ners; Implementasi Kurikulum KBK. Jakarta. 
Al-Hussami, M. et al. (2011) 'Evaluating the Effectiveness of a Clinical Preceptorship Program for Registered Nurses in Jordan', The Journal of Continuing Education in Nursing, 42(12), pp. 569-576. doi: 10.3928/00220124-20110901-01.

Alligood \& Tomey (2002) Nursing Theory Aplication and Utilization. 2nd edn. Mosby, Philadelphia.

Azhary, M. E. (2009) 'Potret Bisnis Rumah Sakit Indonesia. Economic Review', Economic Review, (218).

Billings, D. M. and Halstead, J. A. (2012) Teaching in Nursing, a Guide for Faculty. Fifth. WB Saunders Company, an imprint of Elsevier inc.

Bott, Mohide and Lawlor (2011) 'A clinical teaching technique for nurse preceptors: The five minute preceptor', Journal of professional nursing, 27(1). doi: 10.1016/j.profnurs.2010.09.009.

Burns, C. et al. (2006) 'No Title', Journal of Pediatric Health Care, 20(3), pp. 172183. doi: 10.1016/j.pedhc.2005.10.012.

Canadian Nurses Association (2014) Achieving Excellence in Professional Practice, A guide to preceptorship and mentorship. Ottawa Canada.

Cherry, B. and Jacob, S. (2014) Contemporary nursing, Issues, trends \& management. Mosby, an inprint of Elsevier inc.

Chickerella, B. G. and Lutz, W. J. (2010) 'Professional Nurturance: Preceptorships for Undergraduate Nursing Students', American Journal of Nursing, 81(1).

Davis and Irvine (2003) The role of the university hospital. Los Angeles, San Diego, and San Francisco.

Flanagan, J., Baldwin, S. and Clarke, D. (2000) 'Work-Based Learning as a means of developing and assessing nursing competence', Journal of Clinical Nursing, 9(3), pp. 360-368. doi: 10.1046/j.13652702.2000.00388.x.

Grove, S. K., Burns, N. and Gray, J. R. (2013) The practice of nursing research, Appraisal, synthesis and generation of evidence. Seven. Sounders, an imprint of
Elsevier inc.

Hastono, S. P. (2001) Analisis Data. Universitas Indonesia.

Health Professional Eduction Qaulity-Project; (2011) Laporan survey data dasar pendidikan keperawatan.

Kim, E.-K. and Shin, S. (2017) 'Teaching efficacy of nurses in clinical practice education: A cross-sectional study', Nurse Education Today. Elsevier, 54, pp. 64-68.

Kurniati, A. and Efendi, F. (2012) Kajian Sumber Daya Manusia Kesehatan di Indonesia, Salemba Medika. Jakarta: Salemba Medika. doi: 10.13140/RG.2.1.1440.6804.

Mantzorou (2004) 'Preceptorship in nursing education: is it a viable alternative method for clinical teaching?', pp. 1-10.

Myrick, F. and Yonge, O. (2005) Nursing Preceptorship Connecting Practice and Education. Edited by I. Dana. Philadelpia: Lipincott, William \& Wilkinsis.

Myrick and Yonge (2002) 'Preceptorship and critical thinking in nursing education', Journal of Nursing Education, 41(4), pp. 154-164.

Nursalam, N. and Efendi, F. (2008) Pendidikan Dalam Keperawatan. Jakarta: Salemba Medika.

Pratiknya, A. W. (2011) Dasar-dasar Metodologi Riset Kedokteran dan Kesehatan. Jakarta: Rajawali Pers.

Supranto, J. (2004) Analisis Multivariat: Arti dan Interpretasi. Jakarta: Rineka Cipta.

Tabachnick, B. G. and Fidell, L. S. (2001) Using Multivariate Statistics. USA: A Pearson Education Company.

World Health Organization (2001) Nursing and Midwifery Workforce Management. SEARO Technical Publication No 27.

World Health Organization (2010) 'Framework for Action on Interprofessional Education \& Collaborative Practice', Health Professional Networks Nursing \& Midwifery Human Resources for Health, .

Yonge, O. et al. (2012) 'Preceptorship and Mentorship', 2012, pp. 2-4. doi: $10.1155 / 2012 / 790182$. 